Misr J. Ag. Eng., 26(1): 469- 484

BIOLOGICAL ENGINEERING

\title{
BIO- ENGINEERING APPROACH TO EXPLORE GREENHOUSE PLANT RESPONSES TO ROOT ZONE HEATING
}

\author{
Abdel- Rahman, G. M."
}

ABSTRACT

The present work was carried out through winter seasons 2005-2006 to investigate the effect of root zone heating of plants behavior and yield under greenhouse conditions. This work aimed to explain the increases in plant fresh mass due to root zone heating. The two cultivars of snap beans were used. Seeds were sown directly on 15 th of October 2005 to May 2006, respectively. Four treatments were used, hot water tube, plastic mulch, straw mulch and control (without any especial preparation). The average soil temperature recorded for each previously mentioned treatment were 26, 20.8, 19.9and $18.9^{\circ} \mathrm{C}$ respectively. Plant growth, yield and quality of pods in addition to carbohydrates and fiber content of pods were determined in response to soil heating treatments compared to the control. Results indicated that using hot water treatment gave the highest mean fresh mass (47 gm/pod), the average leaves numbers (24.17 leaft plant), the maximum mean plant height was $153 \mathrm{~cm}$ and plant dry mass (14.3 gm). The tallest plant height was obtained using plastic mulch treatment. There were no significant differences found in the number of shoots per plant and stem diameter in all treatments. No significant differences were found in pod fresh mass, pod diameter and pod length among treatments. The lowest value of total fiber content of pods was found in straw mulch treatment. The highest value of carbohydrates content of pods (15.6 gm) was observed in hot water tube treatment.

\section{INTRODUCTION}

The aim of this research work is to explore the quantitative effect of heating system on the plant root zone from the bio-engineering

1 prospective. From this concept it was assumed that this positive effect of the added heat on plant growth will be considered as the amount of calorie gains by plant.

*Associate Prof., Ag. Eng. Dept., Faculty of Ag., Cairo University.

Misr J. Ag. Eng., January 2009 
Indeed the primarily hypothesis was that heat added to the root zone should have a positive effect on the plant growth rate and developing. As a matter of fact, the first law of thermodynamics, states that energy may be converted to another phase but it never exterminates, therefore, portion of absorbed energy could be transfer throughout the plant root. That amount of these absorbed calories should convert into sugar then starch (carbohydrates) inside the plant parts. This research work will focus on that objective and try precisely to explore this issue as much as it is possible. Consequently, this research will focus on the root zone media environment and its effect on the rate of growth and development of the grown plants as one of the major concern factors for greenhouse growers. Reiss et al. (2007) developed and validated a numerical simulation model of a greenhouse floor heating system using data collected in a greenhouse research. They used modified model to evaluate two different heat pipe diameters and spacing that are typical in the greenhouse industry today: $13 \mathrm{~mm}$ diameter pipe placed on $22.9 \mathrm{~cm}$ centers and $19 \mathrm{~mm}$ diameter pipe placed on $30.5 \mathrm{~cm}$ centers. The model was then further modified to simulate flats with growing media placed on the floor surface. Model simulations were conducted for six different supply water temperatures ranging from 32.2 to $60^{\circ} \mathrm{C}$, while maintaining a target ambient greenhouse air temperature of $15.6^{\circ} \mathrm{C}$. The simulation outputs showed that using the smaller diameter pipes placed closer together resulted in a higher surface heat flux, a higher growing media temperature, and greater temperature uniformity within the growing media, for each supply water temperature simulate. Mulching is one of the important agronomic practices in conserving the soil moisture and modifying the soil physical environment. Though all the mulch treatments improved the soil moisture status, rice husk was found to be superior in maintaining optimum soil moisture condition for crop use. Optimum soil and canopy thermal environment of wheat with limited fluctuations were observed under $\mathrm{RH}$, even during dry periods.

One of the most recent approaches to heating up the root zone media is using an electric cable heating systems offers great possibilities for the development of growing substrates in greenhouses, either by using a heat storage system or by direct substrate heating. The system was established 
and tested by (Rodreguez et al. 2006) who studied and analyzed the influence of the installation depth and spacing of the heating cable, and established management techniques to obtain a heating system capable of providing the substrate located between depths of 75 and $150 \mathrm{~mm}$ with appropriate temperatures for the development of the crop roots in an optimal thermal environment. The heating cable was installed in a greenhouse bench with a sand substrate at three different depths: 150, 225 , and $300 \mathrm{~mm}$, and at three different spacing for each depth of 100 , 150 , and $200 \mathrm{~mm}$, which provided nine different configurations of the heating cable that resulted from combining the different depths and spacing. William et al. (2008) stated that the differences among the different ground covers that are obvious in the mean surface temperatures are also evident in the daily maximum surface temperatures. As expected, pavements have the highest surface temperatures. Bare soil was found to have surface temperatures lower than those of pavement but higher than those of surfaces with plant covers. Different vegetation types under the same climate conditions gave very similar results for ground surface temperature, particularly for mid-summer, when all plants had nearly full density (surface coverage). Monthly-averaged wet weather ground surface temperatures varied relatively little between lands uses $\left(2.5^{\circ} \mathrm{C}\right.$ in July) compared to all weather temperatures $\left(10.4{ }^{\circ} \mathrm{C}\right.$ in July). The information on ground surface temperatures is useful to estimate the impact of different ground covers on thermal pollution of coldwater streams. Also Juan et al. (2007) studied the reaction of the root zone temperature (RZT) as affected by plastic film mulch on the manifestation of symptoms growth and yield of tomato plants. The root zone temperature was highest under black mulch (seasonal mean was 27.58 $\left.{ }^{\circ} \mathrm{C}\right)$, followed by gray $\left(27.08{ }^{\circ} \mathrm{C}\right)$, silver $\left(25.8{ }^{\circ} \mathrm{C}\right)$, and white $\left(24.8{ }^{\circ} \mathrm{C}\right)$ mulches. The plants grown on black mulch showed significantly reduced vegetative growth and fruit yields compared to plants on the other mulches. In conclusion, utilization of plastic mulches that created conditions of high RZT stress resulted in reduced plant growth and yield compared to plants grown at RZTs more favorable to tomato plant growth (optimal RZT $=24.1{ }^{\circ} \mathrm{C}$. An experimental controlled environment system for plant propagation was developed by Wilkerson and Gates (2003) to 
provide three replications of a gradient in root zone temperature treatments to poinsettia cuttings. The system consisted of three propagation chambers and a transpiration chamber for water status tests. It was possible to control both Vapor Pressure Deficit VPD of air and Photosynthesitic Active Radiation (PAR). Two different constant temperature water baths provided water that flowed through aluminum channels welded to opposite sides of an aluminum plate. The temperature of the two water sources could be set to provide a temperature gradient along the width of the plate. Cuttings were propagated in covered aluminum trays oriented along the length of the thermo gradient table to provide multiple cuttings at different media temperatures. The thermo gradient table maintained root zone temperatures within $0.5{ }^{\circ} \mathrm{C}$ of all five treatment set points. Performance of the propagation chambers, some demonstrative results of use, and some limitations in ability to maintain air temperature and relative humidity in high radiation situations are presented. In addition, early, late, and total yields were improved by application mulch and increased the profitability of growing crop. Meanwhile Lamont, (1993), studied the uptake and translocation of essential nutrients, root growth and development and root cell differentiation of plants is directly influenced by root zone temperature Daskalaki and Burrage (1998). Moreover, improving moisture uniformity in the soil and raising air and soil temperatures, create favorable microclimate for the growth of some crops Soltani, et. al., (1995). So, mulching vegetables crops in greenhouse has long been a practice of growers to increase production and promote earlier yields in many of the warm season vegetable crops.

Therefore, the objective of this trial was to study the different soil heating methods and investigate the effect of root zone heating on snap beans plant behavior and yield under different heating treatments.

\section{MATERIALS AND METHODS}

The experiment was performed in autumn seasons of 2005 and 2006 at Dokki Protected Cultivation Experimental Site "Laboratory for Agricultural Climate" (CLAC), Agriculture Research Center (A.R.C.), Ministry of Agriculture and Land Reclamation at Giza Governorate. The 
planting materials used for such research application were two green snap bean cultivars Alhama (undetermined cv.) and Polista (determined cv.). Both cultivars are classified as fine type. Seeds were sown on October $11^{\text {th }}$ and $15^{\text {th }}$ for two winter seasons of 2005- up to may 2006, respectively. Seeds were sown in hills $25 \mathrm{~cm}$ apart to each other and on ridges having $50 \mathrm{~cm}$ width.

A standard single plastic greenhouse of $540 \mathrm{~m}^{2}$ (9 m width, $60 \mathrm{~m}$ long and $3.25 \mathrm{~m}$ height) was divided into five ridges ( $1 \mathrm{~m}$ width and $60 \mathrm{~m}$ long) separated by pathways each of $60 \mathrm{~cm}$ width. All agricultural practices were performed as recommended by Ministry of Agriculture. The experiments were carried out in split plot design with three replicates. The cultivars were arranged in the main plots, whereas the heating root zone treatments were arranged in the sub plots. Each replicate was divided into two lines; one for each cultivar. Three heating root zone treatments were used. The treatments were designed as follows:

\section{1-Hot water tube treatment:}

Using, six P.V.C. tubes ( $1 / 2$ inch diameter and 10 meter long) to carry the hot water for the risosphere area. Two tubes were buried on $15 \mathrm{~cm}$ depth in the middle of each ridge before sowing. All tubes were fed with pump with 100 litter tank. Electricity heater (2000 Watt) was used raise the water temperature to $40^{\circ} \mathrm{C}$.

\section{2-Straw mulch treatment:}

Rice straw (20 kg) with $10 \mathrm{~cm}$ deepth was applied before seven days from sowing seeds, by digging a trench of $40 \mathrm{~cm}$ width in the middle of each ridge.

\section{3-Plastic mulch treatment:}

Sheets of black polyethylene film $1 \mathrm{~m}$ width and $30 \mathrm{~m}$ long with thickness of 50 micron were used as mulch. Strips of plastic mulch were placed after preparing soil and anchored with metal to prevent plastic billowing.

\section{4-Control treatment:}

Seeds were sowed in soil ridges directly in the greenhouse ground as common growers do. 


\section{Measurements:}

\section{1-Growth parameter:}

Three plants were picked up randomly from each experimental plot; two times throughout the whole growing season (after 45 and 100 days from sowing respectively). That was done in order to determine plant height $(\mathrm{cm})$, number of leaves, stem diameter $(\mathrm{mm})$ and shoots number per plant. Total fresh and dry mass of whole plant were determined in $\mathrm{g} / \mathrm{plant}$ or $\mathrm{g} /$ pod. Plants were air dried and then put into the oven at $70^{\circ} \mathrm{C}$ for $24 \mathrm{~h}$.

\section{2- Yield specification and components}

Green pods were picked at green maturity stage. This was carried out 8 times during harvesting season. Harvested pods were counted and weighed at each picking time. Mass of (average of each 3 green pods in grams) pods were taken from the first three harvestings

\section{Computations of energy balance}

The energy balance in this work was calculated on a base of there were two types of heat transfer (from the hot pipes to the soil and from the soil to the root system by conduction plus some rejected by radiation from the soil to the internal air of the greenhouse). Therefore the net heat added to the plant equal the heat added through hot pipes by conduction to the media, minus emissions to the air from the soil by radiation (sum of heat transfer to root system + heat added to the $\left(\mathrm{Q}_{\mathrm{nt}}\right)$ which should be equal:The amount of heat released from the heating system ( $\mathbf{Q}$ pipe(add) $)$ to the greenhouse environment can be calculated as:-

$\mathbf{Q}_{\text {pipe(add) }}=-\left[\mathbf{Q}\right.$ loss(soil -rad.) $+\mathbf{Q}_{\text {diss-soil }}+\mathbf{Q}$ cond(soil-plant $\left.)\right]$.(1)

Where :-

Q loss(soil-rad.) is the heat loss by radiation from the root zone

$\mathbf{Q}$ diss-soil is the heat loss dissipated in the soil consider to be small and has been neglected

Q cond(soil-plant) Is heat gained by root system by conduction

Meanwhile the amount of heat rejected from hot water treatment to the greenhouse environment can be estimated as:-

$\mathbf{Q}_{\mathrm{rej}}=\mathbf{Q}$ loss (soil -rad.) $-[\mathbf{Q}$ cond (soil-plant) $]$ 


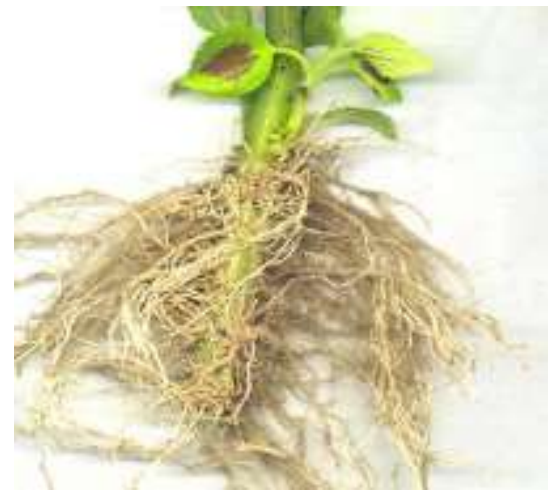

Fig. (1): Bulk of root hair

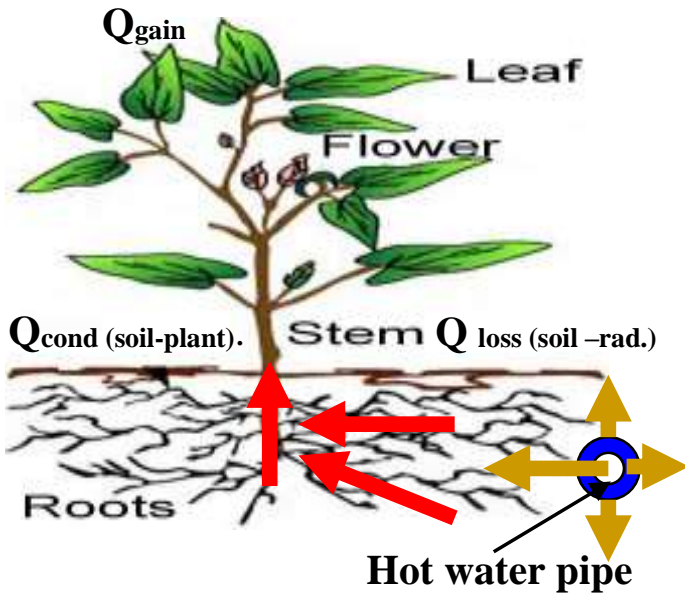

Fig.(2): The direction of heat movement

A- First, heat rejected by radiation $\mathbf{Q}$ loss (soil -rad.) from soil surface to the air.

B- Second, heat transfer by conduction from the soil to the root system which expected to determine as $\mathbf{Q}_{\text {cond (soil-plant). }}$

C- Third, heat radiation from heating pipes to the soil $\mathbf{Q}$ pipe(rad)

\section{I- Regarding the Radiation heat transfer}

Since the emission of greenhouse planting soil through the different four treatments were heated by different rate. These four soil surface treatments were emit heat by radiation, which can be estimated as follows;

$$
\mathrm{Q}_{\mathrm{rad}}=\mathrm{E} \sigma \mathrm{T}^{4}
$$

Where:

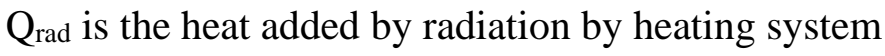

$\mathrm{E}$ is emissions percentage of heat from soil surface and plant ( 0.95 and 0.94 for clay soil and plant respectively)

$\mathrm{T}$ is the soil temperature $\left({ }^{\circ} \mathrm{K}.\right)$

$\sigma$ is Stephan- Boltzmann constant $\left(5.6697 \times 10^{-8} \mathrm{~W} / \mathrm{m}{ }^{\circ} \mathrm{K}\right)$

\section{II- Regarding the conduction heat transfer}

Johnson (1999) mentioned that it can be estimated as the following:-

$$
q_{c d}=\frac{\left(T_{1}-T_{2}\right)}{R}
$$


Where $T_{1}$ and $T_{2}$ are the temperatures $\left({ }^{\circ} \mathrm{C}\right)$ for both the heater system and the seed bed

$R$ is the thermal resistance $\left({ }^{\circ} \mathrm{C} \mathrm{sec} / \mathrm{Nm}\right)$,

$q_{c d}$ is the rate of heat transfer by conduction (W).

$$
\boldsymbol{R}=\frac{\boldsymbol{L}}{\boldsymbol{k} \boldsymbol{A}} \ldots \ldots \ldots \ldots \ldots \ldots \ldots \ldots \ldots \ldots \ldots \ldots \ldots \text { (5) }
$$

$A$ is the conducted area between soil and roots hairs (assumed to be $0.08 \mathrm{~m}^{2}$ )

$k$ is the thermal conductivity coefficient $\left(\mathrm{W} / \mathrm{mK}^{\circ}\right)$ for soil varied from (0.027 as sand and 0.52 as a clay) as an average (0.197), while $\mathrm{k}$ for PVC is 0.21 average.

$\mathrm{L}$ is estimated characteristic length of root (assumed $0.5 \mathrm{~m}$ ).

\section{RESULTS AND DISCUSSION}

The aim of the present research work is to explore the interrelationships between local micro-environment and plant reactions. This research work mainly concentrate on the effect of heating up the plant root zone with the corresponding feedback on the plant growth rate. A bio-system engineering approaches were taken to justify the amount of heat added to or being rejected from the root zone into the greenhouse environment considering its effect on the plant growth rate. These trends were studied on some different levels of explanations as follows.

\section{1- Heat transfer of different soil treatments by radiation.}

Any solid body (as soil) with temperature above zero degree centigrade will emit heat by radiation to the surrounding media around as long as this media temperature less than that body (soil). As it is shown from figure (3), the greatest amount of heat transfer by radiation comes through hot water treatment. The less amount was comes through control treatment due to the lowest temperature.

The other two treatments straw and mulch were just close to and fluctuated with control treatment too. However, the largest gap on the graph of heat transfer between hot water treatment and the other treatments was recognized through January and February as shown in figure(4). Meantime there were no significant differences between the other treatments (mulch and straw) or even with control treatment. 


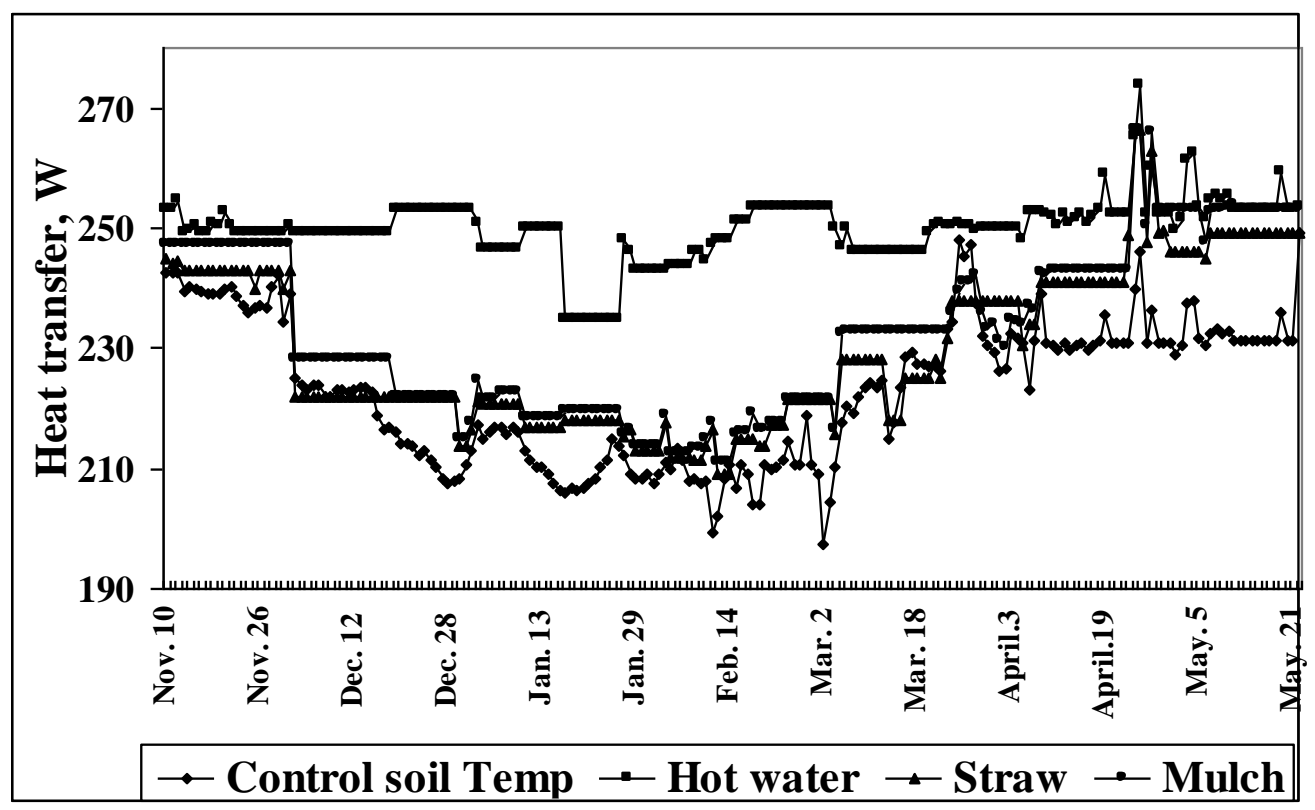

Fig. ( 3 ):Seasonal radiant heat transfer by different soil treatments

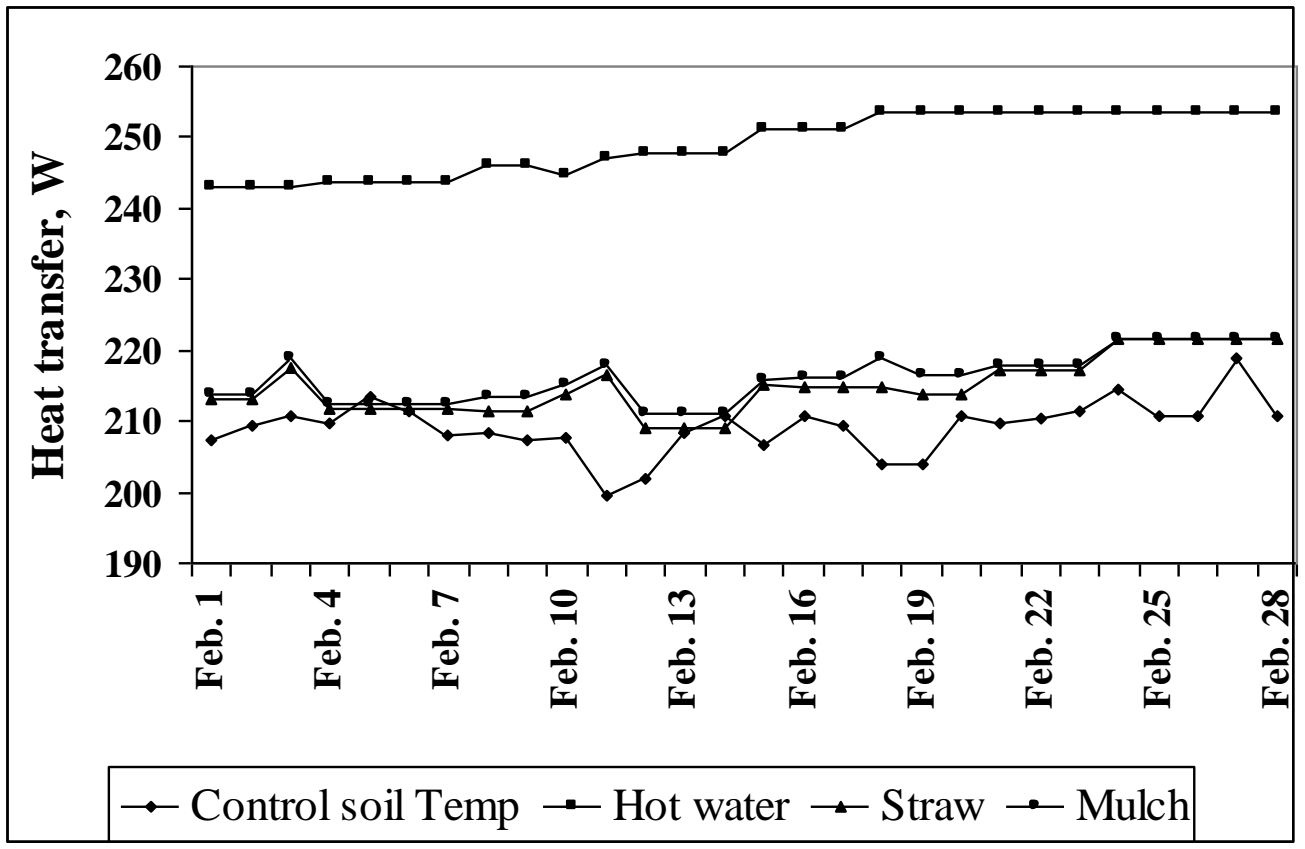

Fig.(4):The high period of radiant heat transfer by different soil treatments 


\section{2- Heat transfer from soil to the root system:}

Regarding heat transfers from the soil to the root system, the prospect of this research work considers it as heat gain, which eventually convert into biomass as the plant grows and develops. Considering the fact that 4 calories are equivalent to 1 gram of sugar, and that 1 watt is equivalent to 0.860 calorie as, consequently, figure (5) and equation (4) show that the maximum amount of heat transfer by conduction to the root system was obtained under hot water treatment.

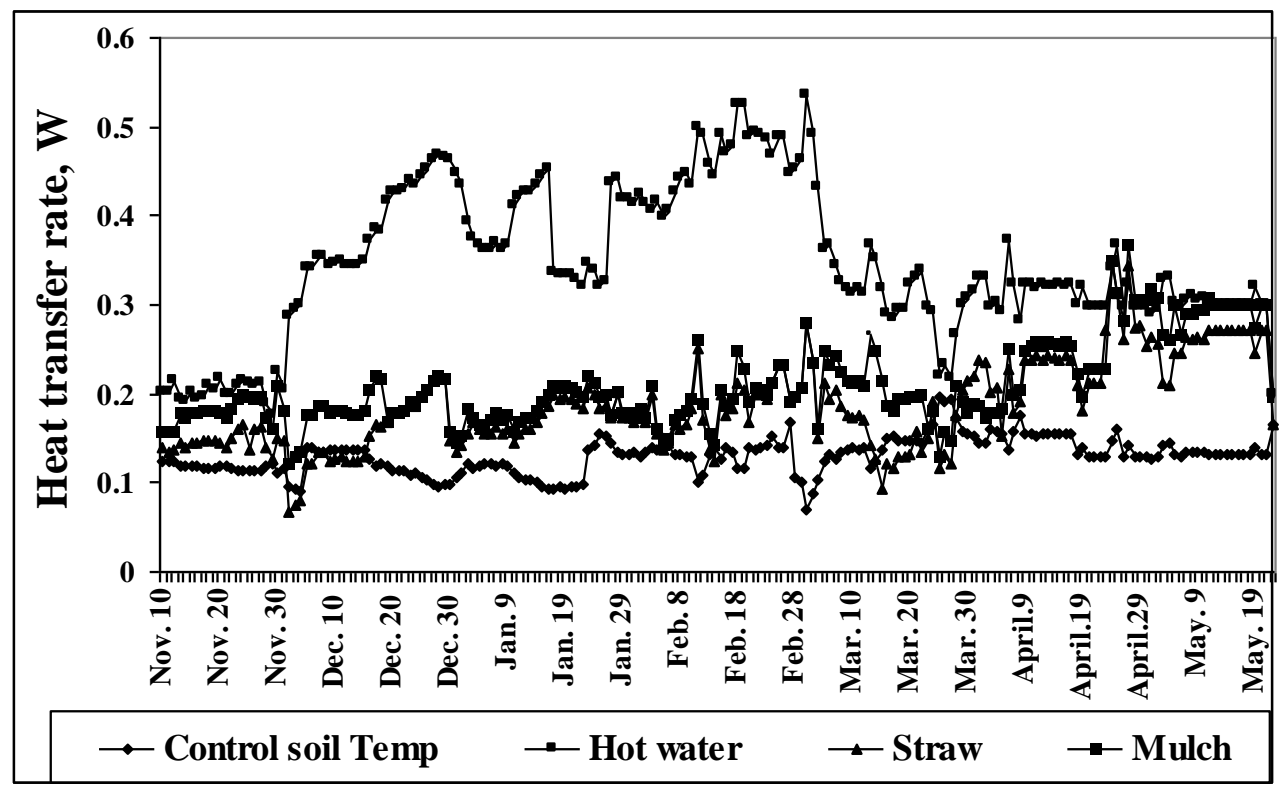

Fig. (5): The amount of heat transfer to the root system by conduction

Similar to the trend shown for the maximum heat transfer by radiation was obtained by hot water. Almost the same trend was noticed for the heat transfer to the root system by conduction under hot water treatment. The maximum heat transfer by conduction was found through the period of February as shown in figure (6).

In the meantime, the largest gap was found at the same period between the hot water treatment and other treatment including control. However there were no significant differences between the other treatments (mulch, straw and control). 


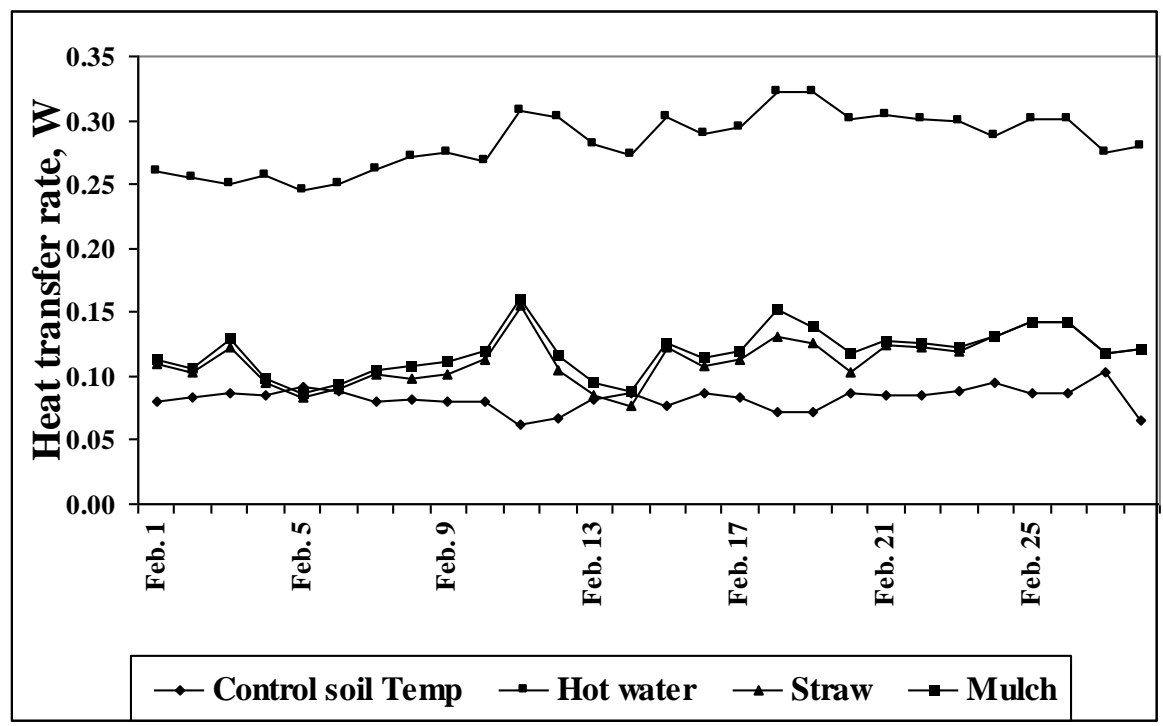

Fig. (6): The maximum amount of heat transfer to the root system by conduction

\section{3- Heat gain by plant}

The amount of heat added by heating up the root media were not only stimulated the root system but it increased water and nutrients uptake rate. Considering the previously mentioned fact that 1 watt equivalent to 0.860 calories and 4 calories are equivalent to 1 gram of sugar, figure (7) shows that the maximum heat gain calories were obtained by hot water treatment.

Also, it was clear that the February period was the highest period as it shown in figure (8). In the meantime, the other treatments including control were having almost the same fluctuation and trend. There was no significant difference between mulch and straw treatments.

\section{4- Estimated added sugar to the grown plant.}

It was obvious from fig. (9) that the greatest amount of estimated converted sugar added to the plant fresh mass ( 8.9 gram) was observed for hot water treatment, then the other treatments 5.4, 4.8 and 3.3 grams for mulch, straw and control respectively. It was also noticed that there are harmony fluctuation between estimated added sugar and plant fresh mass. The same trend was very clear between the estimated converted calories and determined carbohydrate rates for all treatments.

Misr J. Ag. Eng., January 2009 


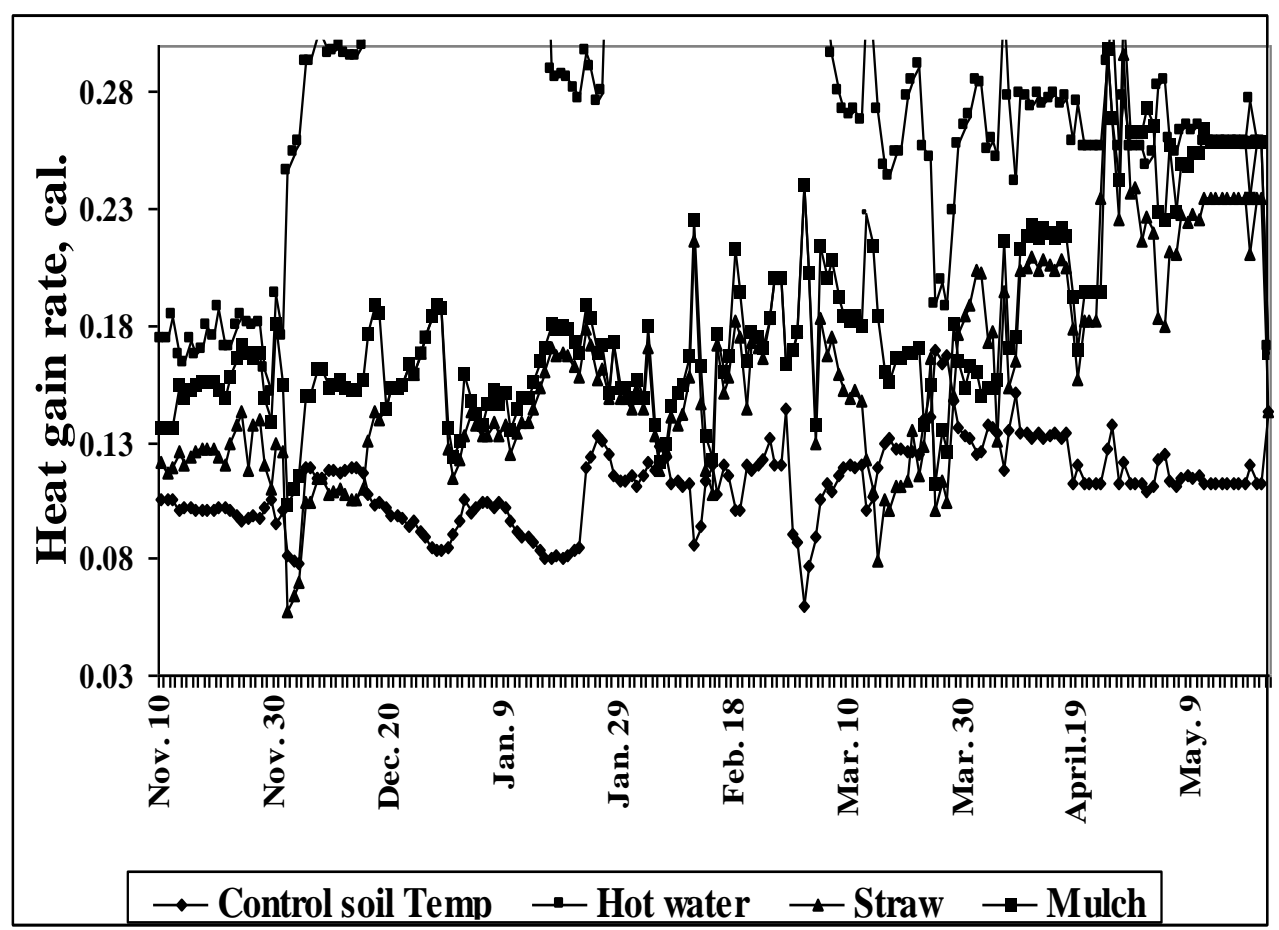

Fig. (7): The amount of calories transfer to the root system by conduction

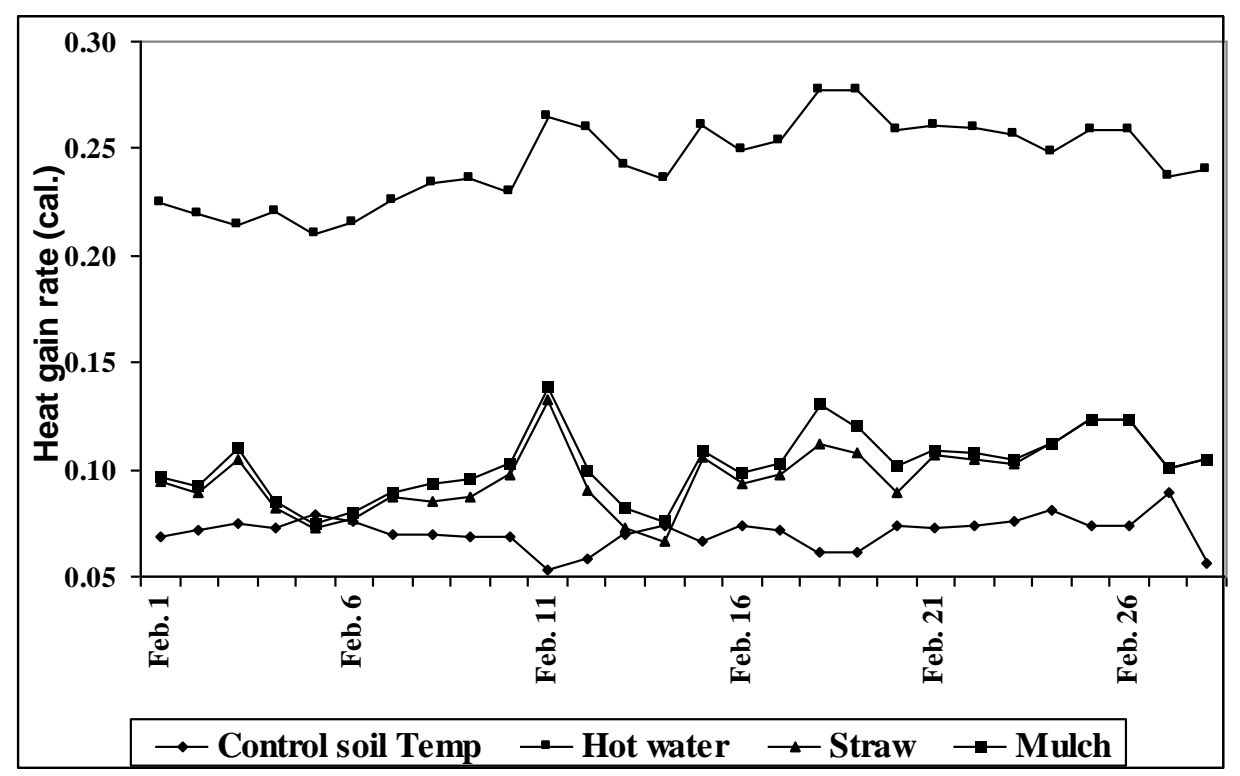

Fig. (8): The maximum amount of calories transfer to the root system by conduction 


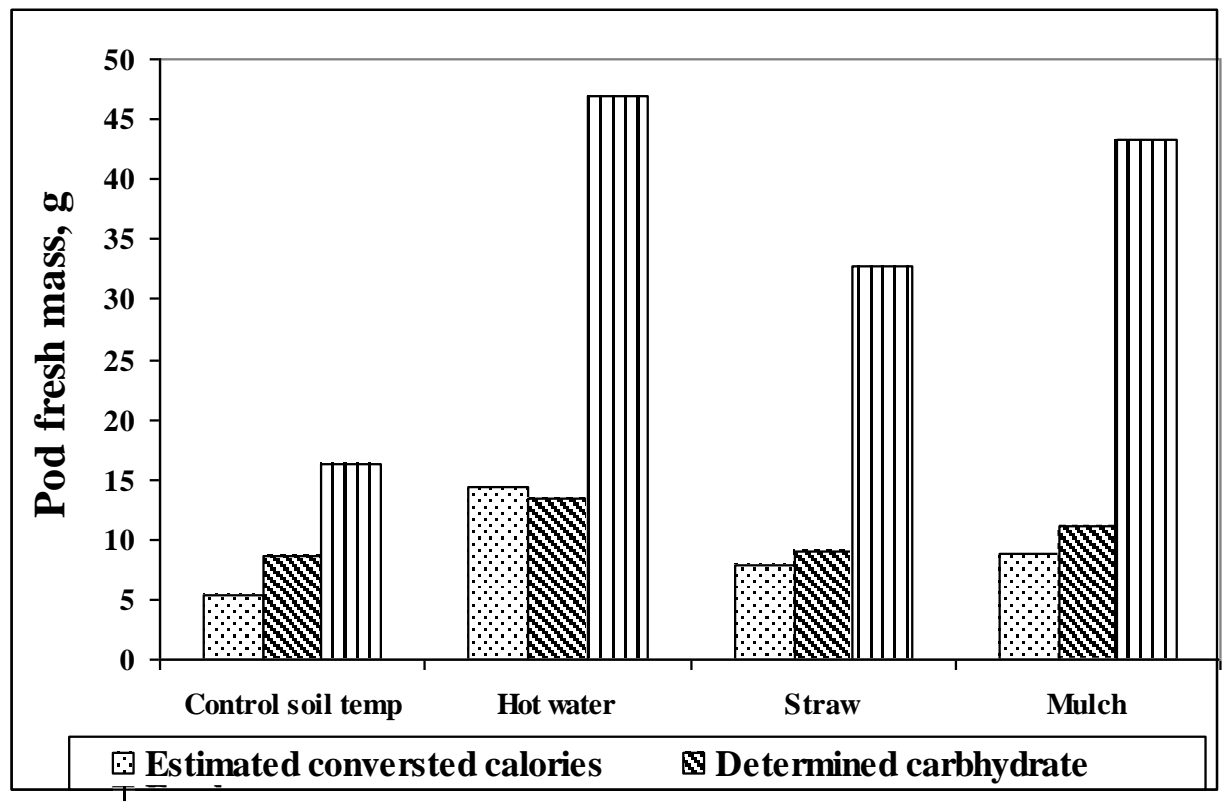

Fig. (9): The amount of estimated sugar added to plant fresh mass For plant fresh and dry masses it was noticed that the hot water treatment record the greatest value for plant fresh mass and number of leaves per plant as mentioned above. But the highest value of plant dry mass was recorded for mulch treatment as shown in figure (10).

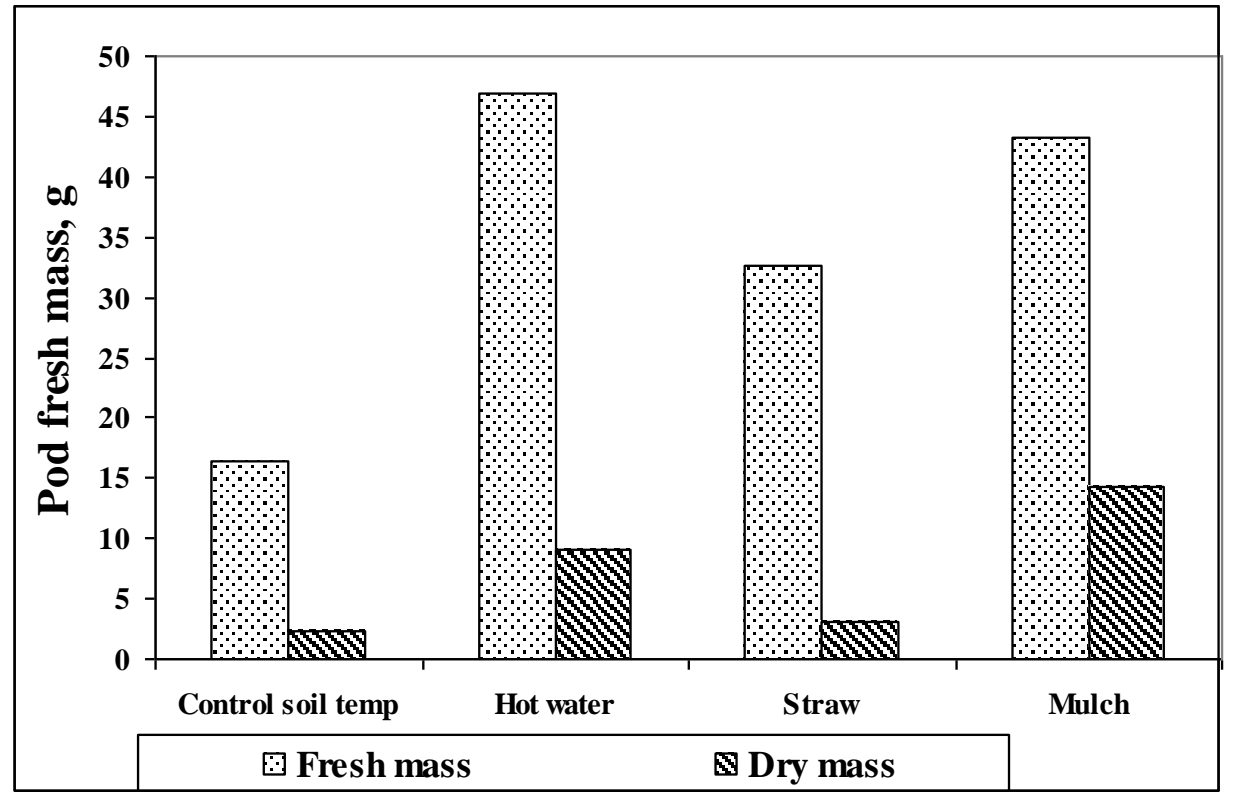

Fig. (10): Fresh and dry weigh of pod per plant 
That may be due to the quick stimulating effect of hot water treatment on root system to absorb soil solution faster than the rate of other plant parts handily as digesting which react as shown on fresh mass.

On the other hand, less heat added by mulch system could give the root system chance to synchronize absorbing rate with the other plant parts rate of digestion, which was positively and slightly higher than hot water treatment.

That is because drying process in the oven and burning procedure may affect the amount of estimated sugar (as added value) obtained by different heating treatments. On the other hand, the faster growth rate of plants in plastic mulch treatment may be due in part to soil temperature increases caused by black plastic mulching (Soltani et al.1995; Jenni et al. 1996), because black mulch absorbs $96 \%$ of short wave radiation and its reflection could be neglected (Teasdale and Abdul-Baki 1995). This absorbed radiation is held by the upper layer of the soil.

\section{CONCLUSION}

It was obvious that the heat added to the root zone has a positive effect on the plant growth rate and developing. This positive effect is due to the amount of absorbed heat by root zone which assumed to be as calories should convert into sugar then starch (carbohydrates) inside the plant parts as an additive. This increase in additive carbohydrates will reflect as additive in plant fresh mass. Therefore the most important results achieved from this research work are:-

1- It was clear that the largest gap of heat transfer was noticed between hot water treatment and the other treatments

2- There were no significant differences between the other treatments (mulch, straw and control).

3- The greatest amount of estimated converted sugar added to the plant fresh mass (8.9 gram) was observed for hot water treatment, then the other treatments 5.4, 4.8 and 3.3 grams for mulch, straw and control respectively.

4- The higher rate of heat added to the root zone the higher fresh mass gains. On the contradictory, the moderate rate of heat added to the root zone the dry mass will eventually be positively affected. 


\section{REFERENCES}

Daskalaki, A. and S. W. Burrage. 1998. Solution temperature and the uptake of water and nutrients by cucumber (cucumis sativusL.) in hydroponics. Acta Hortic. 458:317-322.

Lamont, W. J. Jr. 1993. Plastic mulches for the production of vegetable crops. HortTechnology. 3:35-39.

Juan C. Dı'az-Pe'rez a, Ron Gitaitis b, and Bikash Mandal b 2007. Effects of plastic mulches on root zone temperature and on the manifestation of tomato spotted wilt symptoms and yield of tomato. Scientia Horticulturae 114, 90-95

Jenni, S., D. C. Cloutier, G. Burgeois and K. Stewart. 1996. A heat unit model to predict growth and development of muskmelon to anthesis perfect flowers. Journal of the American Society for Horticulture Science 12: 274-280.

Reiss, E., D. R. Mears, T. O. Manning, G. J. Wulster, A. J. Both. 2007. Numerical modeling of greenhouse floor heating. Transactions of the ASABE. 50(1): 275-284.

Rodreguez, M., R., M. D. FernJndez, F. Maseda, R. Velo. 2006. Influence of depth and spacing of an electric cable heating system in a sand substrate. Applied Engineering in Agriculture. Vol. 22(3): 443-450.

Soltani, N., A. J. LaMar, and A. R. Hamson.1995. Growth analysis of watermelon plants grown with mulches and row covers. Journal of the American Society for Horticultural Science 120): 1001-1009.

Teasdale, J. R., A. A. Abdul-Baki. 1995. Soil temperature and tomato growth associated with black polyethylene and hairy vetch mulches. Journal of the American Society for Horticulture Science120:848853.

Wilkerson. E. G., and R. S. Gates. 2003 . Controlled environment system for Studying root zone temperature effects on cutting propagation. Applied Engineering in Agriculture. Vol. 19(4): 483-489 .

William R. Herb, Ben Janke, Omid Mohseni, Heinz G. Stefan. 2008. Ground surface temperature simulation for different land covers. 
available at www.sciencedirect.com April 2008; accepted 25 April 2008

\section{الملخص العربي \\ مدخل هندسى حيوى لاستجابة النباتات بالبيوت المحمية \\ لتدفئة منطقة المجموع الجذري}

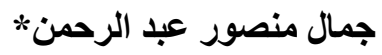

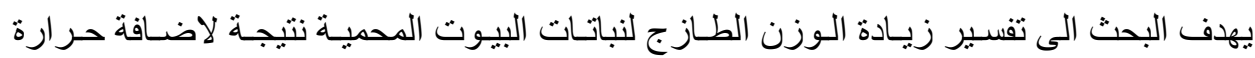

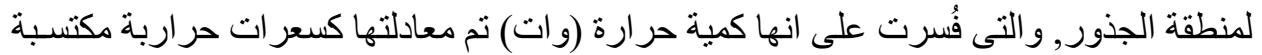

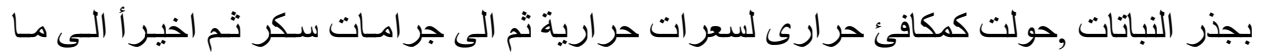

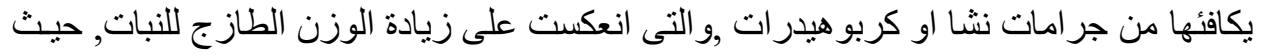

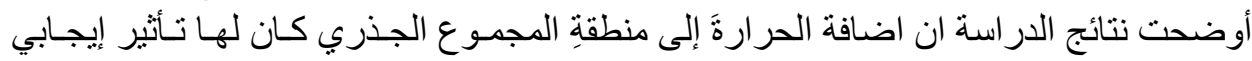

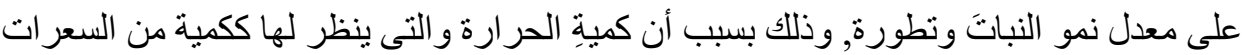

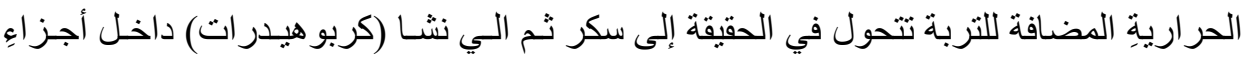

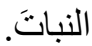

\section{وفد اوضحت نَتُائج الاراسة مايلِي:}

1 ـ أكبر كمية حر ارة منقولة كانت لمعاملة التدفئة يالماء الساخن بالمقارنة بيقية المعاملات. r - لايوجد اى فرق معنوى فى كمية الحر ارة المنتقلة مـن التربـة لجذر النبات بين المعـاملات

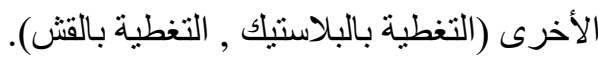

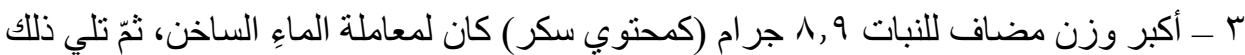

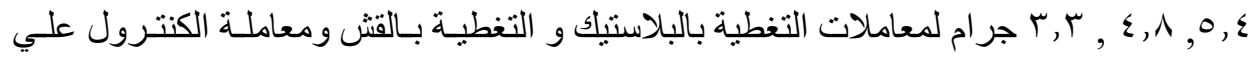
الترتيب .

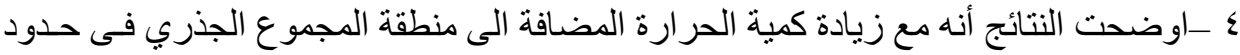

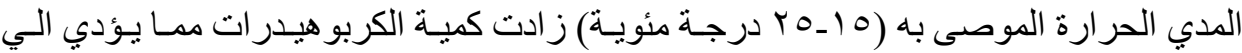

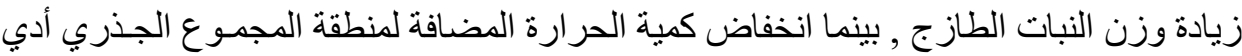
* أستاذ مساعد , قسم الهندسة الزر اعية, كلية الزراعة , جامعة القاهرة. 